\title{
Evaluation of WRF parameterizations for global horizontal irradiation forecasts: A study for Turkey
}

\author{
Selahattin INCECIK ${ }^{1}$, Serim SAKARYA ${ }^{1}$, Seyda TILEV ${ }^{2}$, Abdullah KAHRAMAN ${ }^{3 *}$, \\ Bülent $\mathrm{AKSOY}^{4}$, Erhan CALISKAN ${ }^{5}$, Sema TOPCU ${ }^{1}$, Ceyhan KAHYA ${ }^{1}$ and M. Talat ODMAN ${ }^{6}$ \\ ${ }^{1}$ Istanbul Technical University, Faculty of Aeronautics and Astronautics, Department of Meteorological Engineering, \\ 34469 Maslak, Istanbul, Turkey. \\ ${ }^{2}$ Abu Dhabi Polytechnic, Department of Meteorology, Abu Dhabi, UAE. \\ ${ }^{3}$ Samsun University, Faculty of Aeronautics and Astronautics, Department of Meteorological Engineering, Samsun, \\ Turkey. \\ ${ }^{4}$ Turkish State Meteorological Service, Ankara, Turkey. \\ ${ }^{5}$ Turkiye Sinai Kalkinma Bankasi A.S. \\ ${ }^{6}$ Georgia Institute of Technology, School of Civil and Environmental Engineering, Atlanta, Georgia, USA. \\ *Corresponding author; email: kahraman@meteogreen.com
}

Received: January 6, 2018; accepted: November 26, 2018

\section{RESUMEN}

Este estudio se enfoca a la evaluación de los esquemas de parametrización del modelo WRF cuando se utiliza para los pronósticos de irradiación horizontal global (GHI, por sus siglas en inglés), con el fin de evaluar la viabilidad del uso de energía solar. El área de estudio es la región sudeste de Anatolia (Turquía), cuyas condiciones climáticas son favorables para la generación de energía solar. Los resultados indican que el modelo sobreestimó los valores de GHI calculados por hora para todas las configuraciones en todas las estaciones en comparación con las observaciones. Los valores relativos del error medio del sesgo en cinco estaciones para todas las configuraciones varían de 10 a $21 \%$ para cielo despejado y de 17 a $30 \%$ para condiciones parcialmente nubosas. De manera similar, los valores relativos de la raíz del error cuadrático medio en las cinco estaciones varía de 20 a 39\% para cielo despejado y de 41 a $70 \%$ para condiciones parcialmente nubosas. Sin embargo, hay diferencias notables entre las diversas configuraciones de las parametrizaciones de WRF.

\begin{abstract}
This study deals with the evaluation of the Weather Research and Forecast (WRF) model's parameterization schemes when used for global horizontal irradiation (GHI) forecasts, to assess the feasibility of solar energy utilization. The study area is the southeastern Anatolia (SEA) region of Turkey, with favorable weather conditions for solar energy generation. The results indicate that the values in the hourly output of GHI in the model were overestimated for all configurations at all stations compared to observations. The relative mean bias error values at five stations for all configurations vary between $10-21 \%$ for clear-sky and $17-30 \%$ for partly-cloudy conditions. Similarly, the relative RMSE values at the five stations vary between $20-39 \%$ for clear sky and $41-70 \%$ for partly-cloudy conditions. However, there are noticeable differences among the various configurations of the WRF parameterizations.
\end{abstract}

Keywords: WRF, parameterization schemes, sensitivity, global horizontal irradiation, energy forecasting. 


\section{Introduction}

In general, global horizontal irradiation (GHI) data can be obtained from routine ground-based measurements. However, as solar power plants are integrated into the electricity grids, it is important to forecast how much solar energy will be produced two or three days ahead. The management of total power production considering different sources and the decision making in the energy market depend on the forecasting of GHI. This information is helpful for grid operators in order to better accommodate the variable generation of electricity in scheduling and regulating power. Studies on the impact of clouds and aerosols on GHI are of great importance for reliable GHI forecasting. GHI depends on cloudiness, relative humidity and aerosols; therefore, it is highly variable (Ohtake et al., 2012, 2015; Pedro and Coimbra, 2012; Diagne et al., 2014; Neves and Silva, 2014; Zempila et al., 2016). For example, Zempila et al. (2016) evaluated four short wave (SW) radiation schemes of the Weather Research and Forecast (WRF) model in terms of GHI and found that for all-sky conditions hourly GHI-based on WRF is overestimated for all schemes. Furthermore, all the schemes are found to perform better for clear skies. Ohtake et al. (2015) showed that seasonal and regional variation of cloud types are related to relatively large GHI forecast errors. Thus, accurate short-term solar forecasts are critical for solar power planning and production, and for an efficient use of the fluctuating energy output. Inman et al. (2013) and Diagne et al. (2013) reviewed the current methods used to forecast solar irradiance.

Numerical weather prediction (NWP) models are widely used for weather forecasting and atmospheric research. Some NWP models combine numerous options for physical parameterizations of radiation, cloud microphysics, planetary boundary layer (PBL), surface layer fluxes, turbulence, cumulus convection and others for the representation of sub-grid scale processes. A meteorological model includes parameterizations of radiation and clouds. In general, there are several schemes available to represent each of these processes. NWP models have been proven to be powerful tools for solar radiation forecasting (Lorenz et al., 2009a, b; Rincón et al., 2011; Lara-Fanego et al., 2012; Diagne et al., 2013; Pérez et al., 2013). Early modeling attempts for estimating GHI were based on the fifth-generation Penn State/National Center for Atmospheric Research
(NCAR) Mesoscale Model (MM5) (Grell et al., 1998; Zamora et al., 2003, 2005; Heinemann et al., 2006). In the study of Rincón et al. (2011), the WRF model was applied with $4 \times 4 \mathrm{~km}$ horizontal resolution over the Iberian Peninsula. These models predict GHI by resolving physical processes and using radiation transfer models (RTM) (Morcrette et al., 2007). Studies were reported for various locations of the USA (Zamora et al., 2003, 2005; Mathiesen and Kleissl, 2011) and Europe (e.g., Germany and Spain) (Heinemann et al., 2006; Lorenz et al., 2009a, b). Mathiesen et al. (2013) mentioned that most operational NWP models consistently overpredicted irradiance. Moreover, Lara-Fanego et al. (2012) assessed the WRF-derived solar irradiation predictions in southern Spain and found a striking dependence between model skill in reproducing GHI and cloud cover. Recently Ruiz-Arias et al. (2013) used high quality ground data to test the radiative closure in WRF for USA with the RRTMG (a modified version of the well-known Rapid Radiative Transfer Model [RRTM] scheme in WRF) and Goddard SW radiation schemes in clear-sky conditions, while Zempila et al. (2016) evaluated the differences induced in the WRF model predictions in Greece when using different short wave radiation schemes.

There are several studies indicating the usage of solar energy resources as an alternative to conventional energy in Turkey with a promising prospect for the future (Taşdemiroğlu and Sever, 1986; Topcu and Oney, 1994; Bulut and Büyükalaca, 2007; Bakirci, 2009; Alta et al., 2010; Incecik et al., 2012). Since Turkey is situated between $36^{\circ} \mathrm{N}$ and $42^{\circ} \mathrm{N}$ latitudes, it has been recognized as a region with abundant solar radiation in the Mediterranean belt. The southeastern Anatolia (SEA) region has a highly favorable geographical location for the utilization of solar energy, similar to southern Europe and Mediterranean countries such as Spain, Portugal, France, Italy and Greece. According to the values presented by the General Directorate of Renewable Energy in Turkey (GDRE, 2018), the SEA region in Turkey is the most significant one in terms of annual total solar radiation and sunshine duration.

The aim of this study is to analyze the forecasting skills of the WRF model with four different configurations of physical parameterizations and scheme combinations. Model evaluation is performed for 72-h GHI forecasts in the SEA region of Turkey under 
two different cloud conditions during May 8-10 and August 20-22, 2011. The evaluated forecasts of these two cases were based on hourly values measured on August 20-22, 2011 for clear days (the clear sky condition refers to the absence of clouds) and May 8-10, 2011 for partly cloudy days. The stations selected for this study were Kilis, Ceylanpınar, Bozova, Şırnak, and Mardin in SEA. The meteorological data for these stations were obtained from the Turkish State Meteorological Service (TSMS).

\section{Methods}

\subsection{Study area}

The SEA region is located at $36-38^{\circ} \mathrm{N}$ and covers $57200 \mathrm{~km}^{2}$, approximately $7.5 \%$ of the Turkish territory. The region presents a diverse topography. Its southern part is an almost homogeneous, flat area with a mean elevation of around 744 masl. This area extends around the lower Tigris River basin. On the other hand, the eastern part of the region presents a very complex topography, with steep elevation gradients reaching altitudes over $3800 \mathrm{~m}$.

In terms of GHI, the SEA region is the most significant in Turkey with annual total solar radiation of $1460 \mathrm{kWh} \mathrm{m}^{-2}$ and $2993 \mathrm{~h}$ of sunshine, while average values for Turkey are $1311 \mathrm{kWh} \mathrm{m}^{-2} \mathrm{y}^{-1}$ and $2640 \mathrm{~h}$, respectively (GDRE, 2018). Kilis, Ceylanpınar, Bozova, Şırnak, and Mardin stations have GHI measurements in SEA. Table I shows the geographical characteristics of these stations.

Table I. Geographical characteristics of stations in the study region.

\begin{tabular}{lccc}
\hline Stations & $\begin{array}{c}\text { Latitude } \\
\left({ }^{\circ} \mathrm{N}\right)\end{array}$ & $\begin{array}{c}\text { Longitude } \\
\left({ }^{\circ} \mathrm{E}\right)\end{array}$ & $\begin{array}{c}\text { Altitude } \\
(\text { masl })\end{array}$ \\
\hline Kilis & 36.71 & 37.11 & 640 \\
Ceylanpınar & 36.84 & 40.03 & 360 \\
Bozova & 37.37 & 38.51 & 622 \\
Şırnak & 37.52 & 42.45 & 1350 \\
Mardin & 37.31 & 40.73 & 1040 \\
\hline
\end{tabular}

\subsection{Cloudy conditions}

Clouds and their accompanying weather patterns are among the most important atmospheric phenomena limiting solar radiation at the Earth's surface. GHI has a nonlinear dependency on cloud cover due to its dynamic chaotic characteristics (Paulescu and Badescu, 2011; Chiacchio and Vitolo, 2012). Therefore, clouds are an important source of uncertainty in the prediction of solar irradiance.

Cloudiness or cloud fraction is a meteorological measurement traditionally made by human observers. Cloud cover measurements are reported by meteorological services in SYNOP and METAR reports (González et al., 2012). Because of their subjectivity, these measurements are not always accurate.

The daily sunshine index $(s / S)$ was considered as a criterion, in order to determine the cloud conditions of the study periods. $s / S$ was obtained by normalizing $s$, the bright sunshine duration, with $S$, the astronomical day length. The values of daily index greater than 0.75 were considered descriptive of clear-sky conditions and values between 0.25 and 0.75 were considered as partly cloudy conditions. Simulating solar radiation in clear sky conditions (the absence of clouds) is generally easier than in partly-cloudy ones.

\subsection{Model setup}

The WRF model (Skamarock et al., 2008; Wei et al., 2008) used in the present study (v. 3.3) was integrated using three nested domains with grid spacing values of 36,12 , and $4 \mathrm{~km}$. The SEA region was covered with 4-km grid resolution, as shown in Figure 1.

The simulations were driven based on the National Center for Environmental Prediction (NCEP)

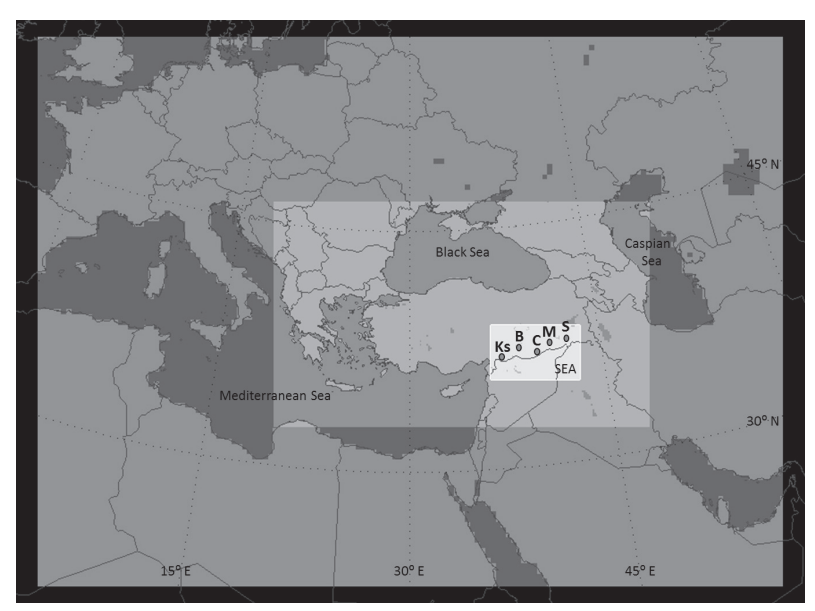

Fig. 1. Model domains and TSMS stations in the region (Ks: Kilis; B: Bozova; C: Ceylanpınar; M: Mardin, and S: Şırnak) 
Global Forecast System (GFS) data. The temporal resolution of the GFS analysis was $6 \mathrm{~h}$, while the spatial resolution was $1^{\circ}$. Model configurations are given in Table II. The atmospheric column was decomposed into 35 vertical levels. Only the innermost domain was used in the evaluation. The WRF model ran for $72 \mathrm{~h}$ in each case. The evaluations of the 72-h GHI forecasts were based on the hourly values measured on August 20-22, 2011 for clear days and on May 8-10, 2011 for partly cloudy days for the given stations in SEA. These dates are chosen after examining observations of all stations during 2011. The model uses two-way nested boundary conditions. No cumulus parameterization was used for domain 3 .

The WRF model offers numerous physical options such as PBL, surface physics, radiation, microphysics and cumulus parameterization. The WRF model was operated with four different configurations defined as WRF0, WRF1, WRF2 and WRF3. The physical parameterizations and scheme choices used in this study are presented in Table III.

Radiation is the main force that regulates the surface energy budget. An atmospheric RTM calculates the radiative transfer of electromagnetic radiation through the atmosphere. Both SW and longwave (LW) radiation parameterizations in an atmospheric model calculate radiation fluxes and heating rates (Price et al., 2013). Specifically, radiation schemes resolve atmospheric heating from radiative flux divergence and surface downward LW and SW radiation. The Rapid Radiative Transfer Model (RRTM) for general circulation models (GCMs) (RRTMG) is the modified version of the RRTM for SW solar irradiance (Clough et al., 2005; Iacono et al., 2008). In the present study, RRTMG (Iacono et al., 2008), RRTM (Mlawer et al., 1997), Fu-Liou$\mathrm{Gu}$ (FLG) (Gu et al., 2011), and Goddard radiation schemes (Chou and Suarez, 1994) were used for SW and LW with different microphysics groups in four

Table II. Model configurations

\begin{tabular}{lccc}
\hline & Domain 1 & Domain 2 & Domain 3 (SEA) \\
\hline Horizontal grid interval & $36 \mathrm{~km}$ & $12 \mathrm{~km}$ & $4 \mathrm{~km}$ \\
Number of horizontal grids & $146 \times 108$ & $220 \times 133$ & $157 \times 97$ \\
Vertical levels & 35 & 35 & 35 \\
Initial conditions (IC) / & GFS 1.0, & Domain 1 & Domain 2 \\
boundary conditions (BC) & 6-h intervals & Two-way & Two-way \\
Nesting & Two-way & Kain-Fritsch & - \\
Cumulus & Kain-Fritsch & & \\
\hline
\end{tabular}

Table III. Description of scheme configurations.

\begin{tabular}{lccccc}
\hline Parameterizations & WRF0 & WRF1 & WRF2 & WRF3 \\
\hline \multirow{2}{*}{ Radiation } & SW & RRTMG & RRTMG & FLG & Goddard \\
\cline { 2 - 5 } LW & RRTM & RRTM & FLG & Goddard \\
\hline Microphysics & WSM6 & Thomson & Thomson & Goddard \\
\hline Surface layer & $\begin{array}{c}\text { Monin-Obukhov } \\
\text { with Carlson-Boland }\end{array}$ & $\begin{array}{c}\text { Monin-Obukhov } \\
\text { with Carlson-Boland }\end{array}$ & $\begin{array}{c}\text { Monin-Obukhov } \\
\text { with Carlson-Boland }\end{array}$ & $\begin{array}{c}\text { Monin-Obukhov } \\
\text { with Carlson-Boland }\end{array}$ \\
\hline Surface physics & Noah & Noah & Noah & Noah \\
\hline Boundary layer & YSU & YSU & YSU & YSU \\
\hline Cumulus & Kain-Fritsch & Kain-Fritsch & Kain-Fritsch & Kain-Fritsch \\
\hline
\end{tabular}


configurations. Table IV presents a comparison of these four radiation schemes.

For example, the number of bands for RRTM and RRTMG are equal to 14 for SW and 16 for LW, respectively. RRTM performs the calculations through the Discrete Ordinates Model (DISORT) for radiative transfer using four streams. As seen in Table IV, both models employ gaseous absorption coefficients extracted from the line-by-line radiation model and the computationally efficient correlated-k method for radiation transfer calculations (Goody et al., 1989). Furthermore, the RRTMG scheme uses a two-stream algorithm for multiple scattering and then uses reduced set of g-intervals for integration over the extinction in each band (Table IV). Moreover, the RRTMG-SW includes the Monte-Carlo Independent Column Approximation (McICA) method to represent sub-grid cloud variability (Barker et al., 2006, 2008). Ruiz-Arias et al. (2013) have shown that the RRTMG has high potential skill for long-term assessment of clear-sky GHI. Furthermore, Mlawer et al. (1997) showed that the RRTM-LW is an accurate and efficient correlated-k, LW RTM. FLG (Fu and Liou, 1993) uses 6 SW and 12 LW spectral bands. FLG uses Delta 4-stream approximation for SW and Delta 2-stream approximation for LW.

The Goddard-SW solar radiation model has been developed at the NASA (Chou and Suarez, 1999). Goddard-SW includes extinction by water vapor $\left(\mathrm{H}_{2} \mathrm{O}\right)$, ozone $\left(\mathrm{O}_{3}\right)$, carbon dioxide $\left(\mathrm{CO}_{2}\right)$, nitrous oxide $\left(\mathrm{N}_{2} \mathrm{O}\right)$, methane $\left(\mathrm{CH}_{4}\right)$, and CFC-11, CFC-12 (Chou et al., 2001). The $\mathrm{SW}$ solar radiation model contains attenuation by $\mathrm{H}_{2} \mathrm{O}, \mathrm{O}_{3}$, oxygen, $\mathrm{CO}_{2}$, aerosols and clouds and the fluxes are calculated at 11 spectral bands, using the two-stream added approximation. Its accuracy is expected to be within a few $\mathrm{W} \mathrm{m}^{-2}$, whereas the atmospheric heating rate between $0.01 \mathrm{hPa}$ and the surface is accurate to within $5 \%$, relative to line-by-line calculations (Chou and Suarez, 1999). Iacono and Nehrkom (2010) showed that the Goddard-SW model produces downward SW surface fluxes that are about $30 \mathrm{~W} \mathrm{~m}^{-2}$ higher than RRTMG-SW. Moreover, the Goddard-LW uses 10 spectral bands. In this study, we employed the newest Goddard scheme under WRF v3.3.

A proper representation of clouds in solar irradiance prediction is rather problematic. Mathiesen et al. (2013) showed that the forecast accuracy is low in case of the regions with dynamic cloud systems.

Table IV. Comparison of radiation schemes.

\begin{tabular}{|c|c|c|c|c|c|}
\hline \multicolumn{2}{|c|}{ Characteristics } & RRTMG & RRTM & FLG & Goddard \\
\hline \multirow{2}{*}{$\begin{array}{l}\text { Number of } \\
\text { bands }\end{array}$} & SW & 14 & 14 & 6 & 11 \\
\hline & LW & 16 & 16 & 12 & 10 \\
\hline \multicolumn{2}{|l|}{$\begin{array}{l}\text { Gases } \\
\text { (optical } \\
\text { parameters) }\end{array}$} & $\begin{array}{c}\mathrm{H}_{2} \mathrm{O}, \mathrm{CO}_{2}, \mathrm{O}_{3}, \\
\mathrm{~N}_{2} \mathrm{O}, \mathrm{CH}_{4}, \mathrm{O}_{2}, \\
\text { and four types } \\
\text { of halocarbons: } \\
\mathrm{CFC}-11, \mathrm{CFC}- \\
\begin{array}{c}12, \mathrm{CFC}-22 \\
\mathrm{CCl}_{4}\end{array}\end{array}$ & $\begin{array}{c}\mathrm{H}_{2} \mathrm{O}, \mathrm{CO}_{2}, \mathrm{O}_{3} \text {, } \\
\mathrm{N}_{2} \mathrm{O}, \mathrm{CH}_{4}, \mathrm{O}_{2}, \\
\mathrm{CO} \text {, and four } \\
\text { types of halocarbons: } \\
\text { CFC-11, CFC-12, CFC- } \\
22, \mathrm{CCl}_{4}\end{array}$ & $\begin{array}{c}\mathrm{H}_{2} \mathrm{O}, \mathrm{CO}_{2}, \mathrm{O}_{3}, \mathrm{~N}_{2} \mathrm{O} \\
\mathrm{CH}_{4}, \mathrm{O}_{2}, \mathrm{CO}, \mathrm{NO}, \mathrm{SO}_{2}, \\
\mathrm{NO}_{2} \text {, and three types of } \\
\text { halocarbons: } \\
\text { CFC-11, CFC-12, } \mathrm{CH}_{3} \mathrm{Cl}\end{array}$ & $\begin{array}{c}\mathrm{H}_{2} \mathrm{O}, \mathrm{CO}_{2}, \mathrm{O}_{3}, \\
\mathrm{~N}_{2} \mathrm{O}, \mathrm{CH}_{4}, \\
\text { and two types of } \\
\text { halocarbons: } \\
\text { CFC-11, CFC-12 }\end{array}$ \\
\hline \multicolumn{2}{|l|}{$\begin{array}{l}\text { Gaseous } \\
\text { absorption }\end{array}$} & $\begin{array}{c}\text { Correlated } \\
\text { k-distribution method }\end{array}$ & $\begin{array}{l}\text { Correlated } \\
\text { k-distribution } \\
\text { method }\end{array}$ & $\begin{array}{c}\text { Correlated } \\
\text { k-distribution } \\
\text { method }\end{array}$ & $\begin{array}{l}\text { Correlated } \\
\text { k-distribution } \\
\text { method }\end{array}$ \\
\hline \multicolumn{2}{|c|}{ Cloud overlap } & $\begin{array}{l}\text { Maximum-Random } \\
\text { cloud overlapping }\end{array}$ & $\begin{array}{l}\text { Maximum-Random } \\
\text { cloud overlapping }\end{array}$ & $\begin{array}{l}\text { Maximum-Random } \\
\text { cloud overlapping }\end{array}$ & $\begin{array}{l}\text { Maximum-Random } \\
\text { cloud overlapping }\end{array}$ \\
\hline \multicolumn{2}{|l|}{$\begin{array}{l}\text { Calculation } \\
\text { of flux }\end{array}$} & $\begin{array}{l}\text { Two-stream } \\
\text { algorithm }\end{array}$ & $\begin{array}{c}\text { Four-stream adding } \\
\text { DISORT }\end{array}$ & $\begin{array}{l}\text { Delta 4-stream (SW) } \\
\text { Delta 2-stream (LW) }\end{array}$ & $\begin{array}{l}\text { Two-stream } \\
\text { algorithm }\end{array}$ \\
\hline
\end{tabular}


In the present study, the WRF Single-Moment 6-Class (WSM6) (Hong and Lim, 2006) and the Thompson (Thompson et al., 2004) microphysics schemes were used for representing microphysical processes in clouds while only the Kain-Fritsch scheme (Kain and Fritsch, 1990; Kain, 2004) was considered for cumulus parameterization.

In microphysics, the WSM6 scheme uses recent scientific developments regarding ice nucleation and includes a dependence on aerosol concentration (Skamarock et al., 2008). Besides, the scheme includes a parameterization for calculating the direct radiative effects of several types of aerosol, including maritime, continental, urban, mineral dust, soot (black carbon), and sea salt. The WSM6 has been one of the options of microphysical processes in the WRF model since 2004. It is based on the revised ice-microphysics suggested by Hong, Dudhia and Chen (HDC) (Hong et al., 2004; Hong and Lim, 2006). In addition to the characteristics mentioned above, the WSM6 behaves realistically in response to the appropriate grid resolvable forcing (Hong and Lim, 2006).

The Thompson scheme, developed for use in WRF and other mesoscale models, is another scheme used for parameterization of microphysics. The Thompson microphysics scheme includes improvements to the earlier bulk scheme of Reisner et al. (1998). It was tested and compared with idealistic case studies, specifically for mid-latitudes (Hall et al., 2005).

There are many different PBL parameterization schemes in the literature (Kleczek et al., 2014). Many of them are designed to perform well during specific weather conditions. The variation of the predicted parameters such as temperature, mixing height and GHI with different parameterization schemes were examined by several investigators. For example, Shin and Hong (2011) compared five PBL schemes in the WRF model for a single day from a field program. They reported a large variation in the mixing height values computed by the five schemes both in daytime and nighttime. Hu et al. (2010) compared the 3 -month mean diurnal variations of the simulated mixing heights, using different combinations of parameterization schemes in the WRF model with the observed values for Southeast Texas. Similarly, Han et al. (2008) evaluated five PBL schemes in the MM5 model for the East Asian domain and reported a large difference in the mixing heights predicted by the various combinations of parameterization schemes. RuizArias et al. (2008) conducted an evaluation study for the performance of different parameterizations of the model. In this study, the model's performance was found highly dependent on the sky conditions. For example, solar radiation RMSE values were about one order of magnitude higher during broken-clouds and overcast conditions compared to clear-sky ones. More recently, Zempila et al. (2016) evaluated the shortwave radiation schemes such as Dudhia, updated RRTMG, updated Goddard and the GFDL schemes based on the WRF-model derived GHI predictions for cloudy and cloudless conditions. All SW radiation schemes presented better GHI predictions during the warm period due to the reduced presence of clouds.

The Monin-Obukhov similarity theory with Carlson-Boland viscous sublayer was also used for representing surface-layer parameterization; the Noah model was selected as land surface model for surface physics. The Yonsei University (YSU) scheme for PBL (Hong and Lim, 2006) and the Kain-Fritsch scheme for cumulus parameterizations (Kain and Fritsch, 1990) were used.

\subsection{Error metrics}

In the present study, we employed two error metrics for the evaluation of the model simulations according to the observations: mean bias error (MBE) and root mean square error (RMSE).

$\mathrm{MBE}=\frac{1}{n} \sum_{i=1}^{n}\left[x_{e}(i)-x_{m}(i)\right]$

$\operatorname{RMSE}=\left[\frac{1}{n} \sum_{i=1}^{n}\left(x_{e}(i)-x_{m}(i)\right)^{2}\right]^{1 / 2}$

where $x_{\mathrm{e}}$ is the estimated data and $x_{\mathrm{m}}$ is the measured data. In addition to these metrics, normalized values rMBE and rRMSE are defined as relative MBE and relative RMSE, respectively. Nearest grid-point is used for verification with the station observations.

\section{Results and discussion}

This article investigates the forecasting skills of solar radiation by the WRF model with different configurations of physical parameterization and scheme combinations, both in terms of partly-cloudy and 
clear-sky conditions at each site in the SEA region. This evaluation will improve our understating of the strengths and weaknesses of the four different configurations of the WRF model in forecasting hourly GHI values in the region.

In this study, the three days ahead hourly GHI simulations based on the four different configurations were evaluated for the two 3-day simulation periods representing different cloud conditions including May 8-10, 2011 (partly cloudy) and August 20-22, 2011 (clear sky) in the regions. Model predictions were compared to GHI measurements from installed pyranometers at five meteorological stations in SEA. The results are structured and analyzed in two parts as follows:

\subsection{Partly cloudy case (May 8-10, 2011)}

The period May 8-10, 2011 during which the $s / S$ varied between 0.25 and 0.75 , was selected as the partly-cloudy case. Seventy two-hour simulation results of the model based on the four different configurations named WRF0, WRF1, WRF2 and WRF3 for partly cloudy days at five stations are shown in Figure 2.

The MBE and RMSE are computed for all stations and on an average throughout the SEA region according to Eqs. (1) and (2); the results are shown in Table V. The rMBE and rRMSE values at each station for all configurations in partly cloudy conditions are calculated and shown in Figures 3 and 4, respectively. MBEs are found positive indicating overestimation of GHI for the partly cloudy conditions at five stations and for all configurations (Table V). The findings are supported by the results of Zempila et al. (2016). The overestimated WRF-derived hourly GHI values can also be clearly seen in Figure 2. As seen in Table V, MBE varies from 49.49 (WRF2) to $80.98 \mathrm{~W} \mathrm{~m}^{-2}$ (WRF3) depending on the configuration and site of the region for the partly cloudy situation.

Moreover, the partly-cloudy days on May 8-10, 2011 are linked with high RMSEs. For example, the regional average RMSE for the scheme configurations varied between 152.29 and $161.82 \mathrm{~W} \mathrm{~m}^{-2}$ at SEA. These results are in agreement with the findings of Mathiesen and Kleissl (2011), who also presented higher biases during partly-cloudy conditions in the USA. The MBE values reported for NAM forecasts under moderately-cloudy conditions in the USA are positive and vary between 10.8 and $62.6 \mathrm{~W} \mathrm{~m}^{-2}$ while the RMSE values vary between 93.5 and $149 \mathrm{~W} \mathrm{~m}^{-2}$.

Furthermore, from the relative view of the errors, the rMBE varies between 17 and 30\% depending on the configuration and site while the rRMSE varies between 41 and 70\%, respectively (Figs. 3 and 4). The difference between the forecasting values of WRF-derived hourly GHI and the observations shows that the WRF3 combination has the highest error among the four configurations in the region for partly-cloudy situation (Fig. 2). The lowest RMSE was found in Bozova (in the range of 139.49 and $151.40 \mathrm{~W} \mathrm{~m}^{-2}$, depending on the configuration) while the highest was found at Ceylanpınar (177.23 and $191.17 \mathrm{~W} \mathrm{~m}^{-2}$ ) and Mardin (173.52 and 179.68 $\mathrm{W} \mathrm{m}^{-2}$ ).

In summary, the WRF model with the four configurations used in the study did not adequately represent the fluctuations in the partly-cloudy case. This may be explained by the impact of clouds and aerosols (Sezen et al., 2013). Although the impacts of the aerosols were not considered in this study, spring is the favorable season for dust transport from the southern desert areas to many regions of Turkey including SEA. Specifically Mardin is very well known as a dusty city. As a final remark for the partly-cloudy, case the WRF0 configuration had a better performance compared to other configurations.

\subsection{Clear-sky case (August 20-22, 2011)}

In this study, the August 20-22, 2011 period has been selected to represent the clear sky situations using $s / S$ values higher than 0.75 . The modelled and measured GHI values for $72 \mathrm{~h}$ at SEA sites are shown in Figure 5. As seen from Table VI, MBEs are positive, indicating overestimation of GHI for the clear-sky days at the five stations and for all configurations, similar to the partly cloudy case in May. The results of the WRF model at each site in the region, in terms of performance of each statistical metric, are also shown in Figures 6 and 7. The comparison of the four model configurations presents significant differences in the relative MBE and RMSE at the five sites in the region. The relative MBE is between 10 and $18 \%$ and the relative RMSE is between 20 and $39 \%$ throughout the region depending on the WRF model configuration (Figs. 6 and 7). Furthermore, from a regional perspective, the average MBE and RMSE 
a)

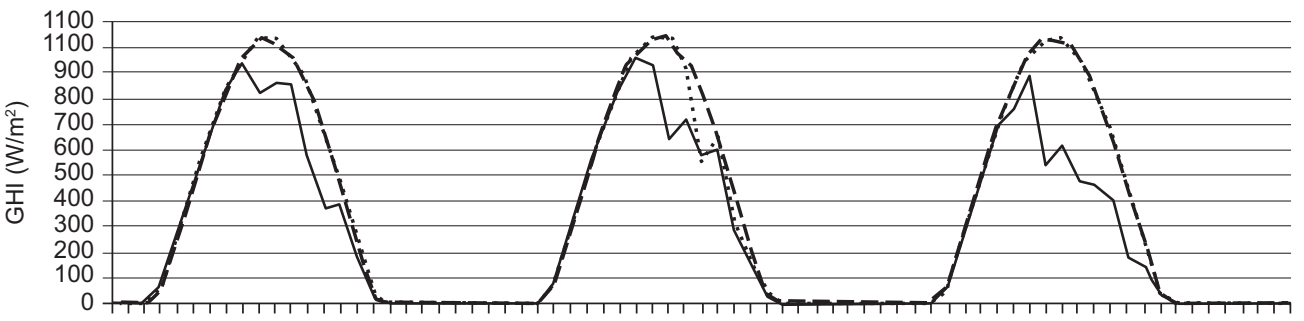

b)

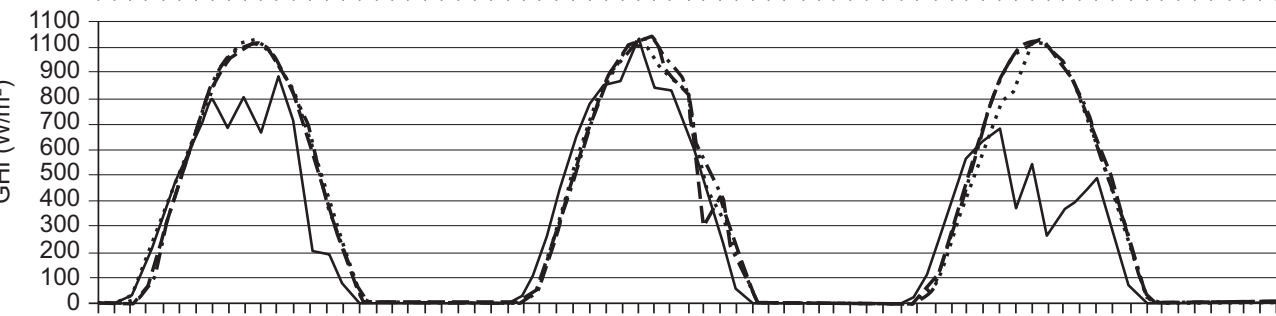

c)

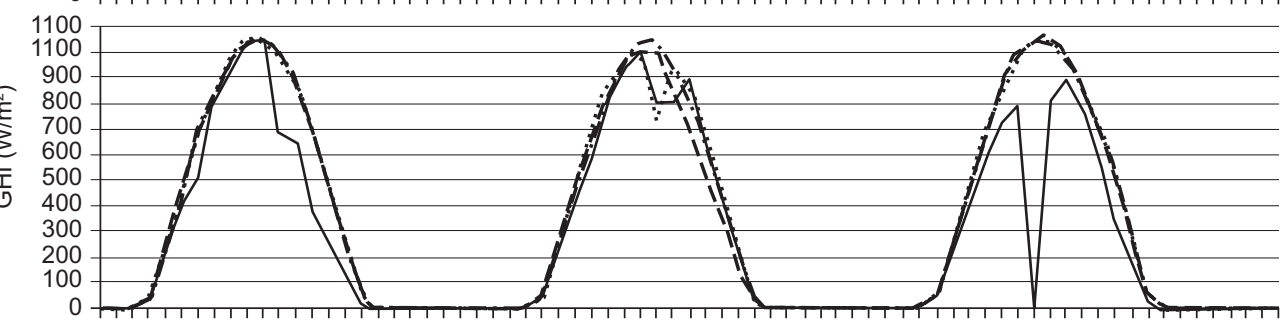

d)

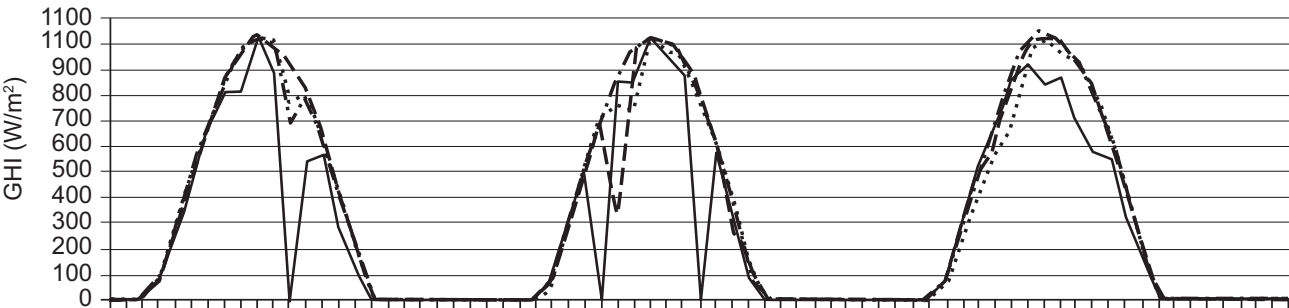

e)

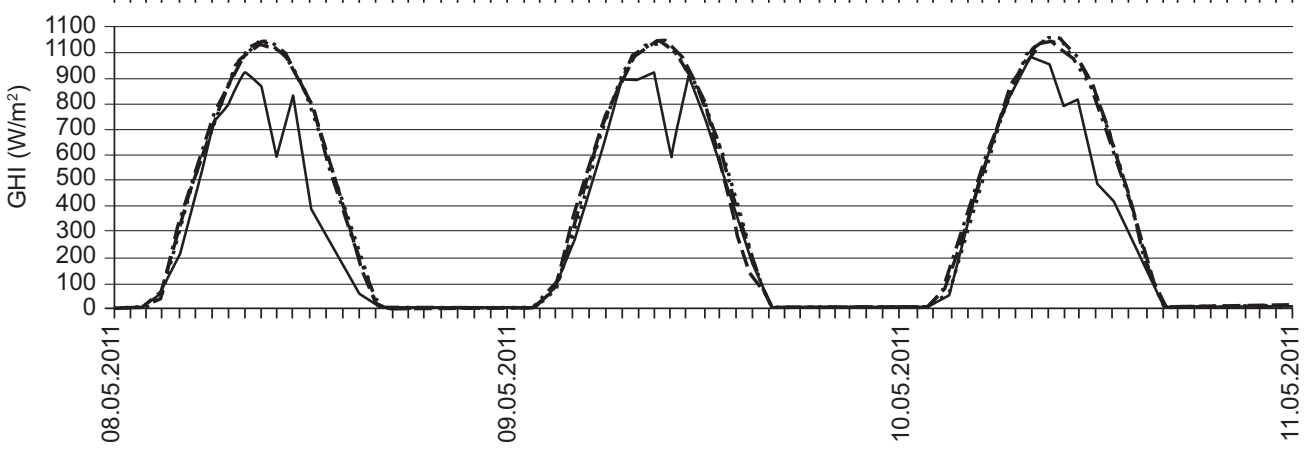

Fig. 2. Modelled and measured GHI values at the TSMS stations: (a) Bozova, (b) Ceylanpinar, (c) Kilis, (d) Mardin, and (e) Şırnak in the SEA region for May 8-10, 2011 period with partly cloudy conditions. 
Table V. MBE $\left(\mathrm{W} \mathrm{m}^{-2}\right.$ ) and RMSE (W m ${ }^{-2}$ ) values on May 8-10, 2011 for partly-cloudy conditions for SEA.

\begin{tabular}{llrrrr}
\hline Site & Statistics & WRF0 & WRF1 & WRF2 & WRF3 \\
\hline \multirow{2}{*}{ Bozova } & MBE & 62.06 & 64.58 & $\mathbf{5 8 . 8 8}$ & 73.89 \\
\cline { 2 - 6 } Ceylanpınar & RMSE & $\mathbf{1 3 9 . 4 9}$ & 141.54 & 139.94 & 151.40 \\
\cline { 2 - 6 } & RBE & $\mathbf{6 3 . 7 6}$ & 68.40 & 67.88 & 80.98 \\
\hline \multirow{2}{*}{ Kilis } & MBE & $\mathbf{1 7 7 . 2 3}$ & 183.16 & 183.30 & 191.17 \\
\hline \multirow{2}{*}{ Mardin } & RMSE & $\mathbf{1 4 8 . 8 9}$ & 151.44 & 152.44 & 159.48 \\
\hline \multirow{2}{*}{ Şırnak } & RBE & 53.61 & 63.12 & $\mathbf{5 3 . 1 1}$ & 70.13 \\
\hline \multirow{nyyyyy}{*}{ Average } & RME & $\mathbf{1 7 3 . 5 2}$ & 179.68 & 174.35 & 175.98 \\
\hline & RMSE & 122.32 & 121.87 & $\mathbf{1 2 1 . 0 7}$ & 131.07 \\
\hline
\end{tabular}

Note: minimum errors are shown in bold.

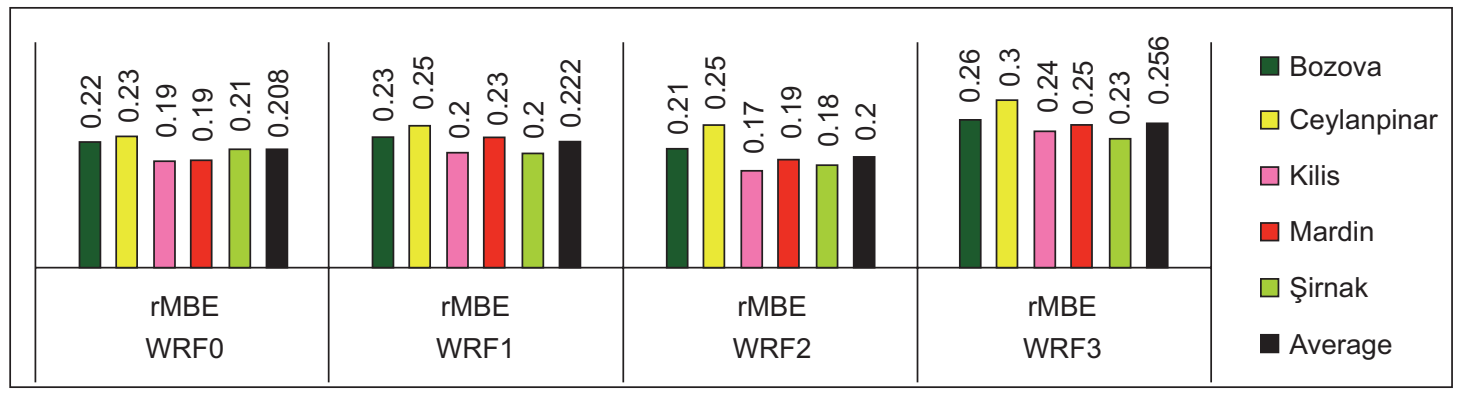

Fig. 3. rMBE values for the SEA region on May 8-10, 2011 for partly-cloudy conditions.

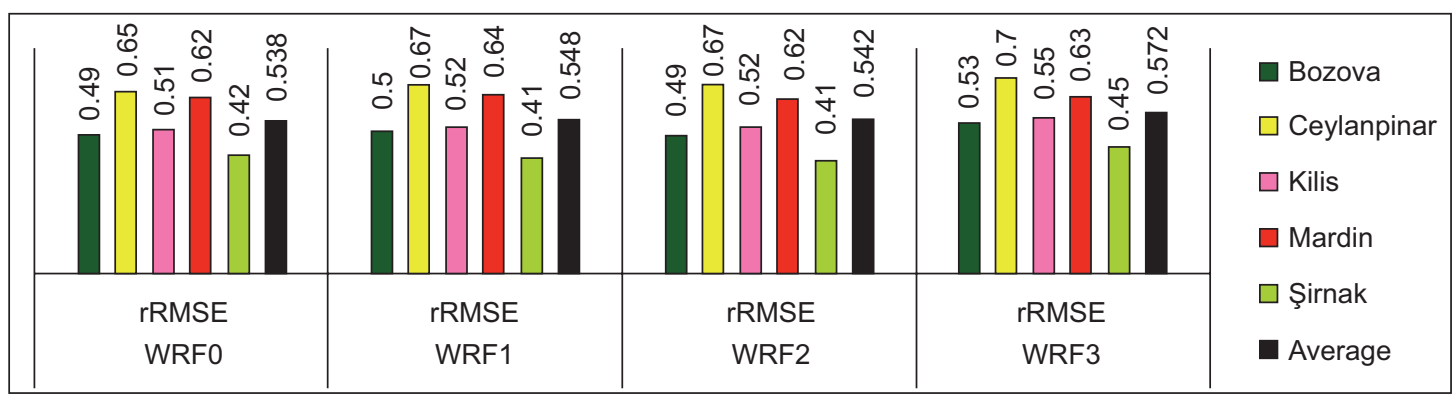

Fig. 4. rRMSE values for the SEA region on May 8-10, 2011 for partly-cloudy conditions. 
Table VI. MBE $\left(\mathrm{W} \mathrm{m}^{-2}\right.$ ) and RMSE $\left(\mathrm{W} \mathrm{m}^{-2}\right)$ values for SEA region on August 20-22, 2011 for clear-sky conditions.

\begin{tabular}{llllll}
\hline Site & Statistics & WRF0 & WRF1 & WRF2 & WRF3 \\
\hline \multirow{2}{*}{ Bozova } & MBE & $\mathbf{4 5 . 0 3}$ & 45.90 & 45.27 & 55.76 \\
\cline { 2 - 6 } Ceylanpınar & RMSE & $\mathbf{9 0 . 8 1}$ & 91.43 & 92.65 & 102.72 \\
\cline { 2 - 6 } & MBE & 46.97 & 46.28 & $\mathbf{4 4 . 8 6}$ & 55.32 \\
\hline \multirow{2}{*}{ Kilis } & RMSE & 71.75 & $\mathbf{6 9 . 1 0}$ & 69.23 & 82.04 \\
\hline \multirow{2}{*}{ Mardin } & RMSE & 81.70 & $\mathbf{7 9 . 7 7}$ & 87.41 & 93.37 \\
\hline \multirow{2}{*}{ Şırnak } & MBE & 34.68 & 34.72 & $\mathbf{3 1 . 4 7}$ & 41.33 \\
\hline \multirow{2}{*}{ Average } & MBSE & 57.71 & 57.63 & $\mathbf{5 7 . 4 3}$ & $\mathbf{7 0 . 1 9}$ \\
\cline { 2 - 6 } & RMSE & 39.89 & 39.54 & $\mathbf{3 5 . 9 8}$ & 47.94 \\
\hline
\end{tabular}

Note: minimum errors are shown in bold.

values varied in the ranges of $36.73-48.26 \mathrm{~W} \mathrm{~m}^{-2}$ and 71.24-81.13 $\mathrm{W} \mathrm{m}^{-2}$, respectively, depending on the configuration.

According to the statistical metrics, the model performance is better for the clear sky case than the partly cloudy conditions, as expected.

GHI forecast by the WRF2 model configuration is close to the observations particularly at Şırnak and Mardin, with the lowest RMSE values of 55.42 and $57.43 \mathrm{~W} \mathrm{~m}^{-2}$, respectively (Table VI). These sites are located at the rugged mountainous area with higher altitudes in SEA (Table I). RMSE values are supported by the findings of Ohtake et al. (2015) in Japan using the Japan Meteorological Agency (JMA) mesoscale model.

In the WRF2 model configuration, rMBE varies between 10 and $17 \%$ while rRMSE varies between 20 and $35 \%$ depending on the site within the study region. These results by the WRF2 configuration are in agreement with the results by Diagne et al. (2014), who reported rMBE of $6.34 \%$ and rRMSE of $37.18 \%$ at Saint Pierre together with an rMBE of $16.08 \%$ and rRMSE of $57.3 \%$ at Tampan, two sites on Reunion Island in the Indian Ocean. Generally, the statistics of WRF2 indicated slightly better performance than WRF0 and WRF1 and significantly better performance than WRF3 for clear sky conditions. WRF3 presents poor results compared to the other configurations. Hence, we can emphasize that it is a combined effect of all parameterization schemes which translates into a good simulation of GHI by the WRF model except for the WRF3 combination.

\section{Conclusions}

In the present study, the skill of the WRF model in forecasting hourly GHI values in the SEA region of Turkey was assessed at five sites and under two different cloud conditions with four different combinations of parameterization schemes to improve our understanding of which schemes perform better.

The skill of the WRF model was evaluated through the combination of MBE and RMSE at the five sites in the region. The performance of the GHI forecasting up to three days ahead based on the WRF mesoscale model applications including physical parameterizations (radiation, microphysics, PBL, surface layer, surface physics, and cumulus) with 
a)

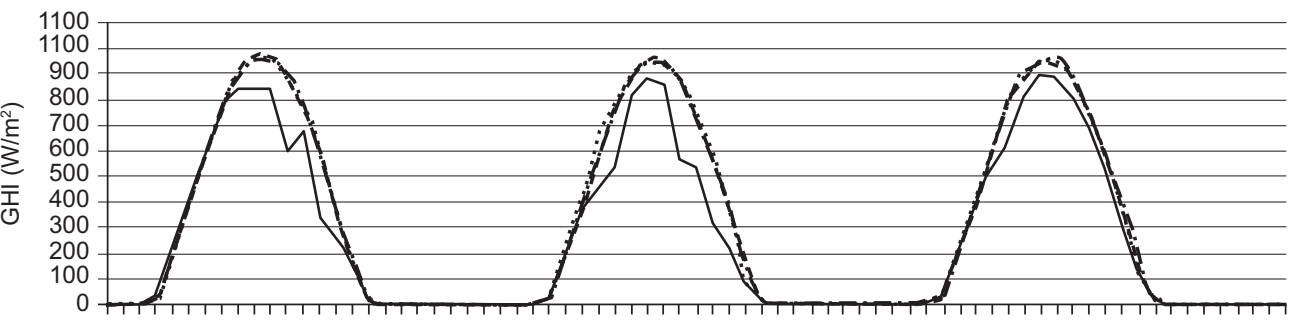

b)

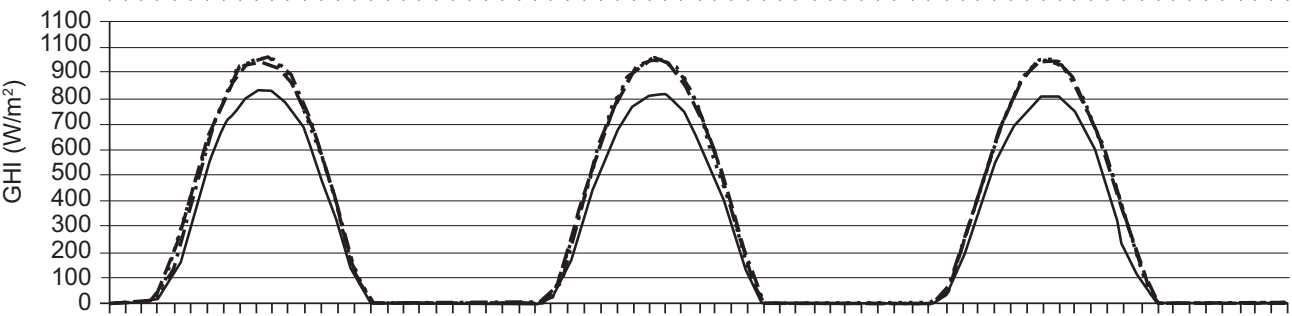

c)

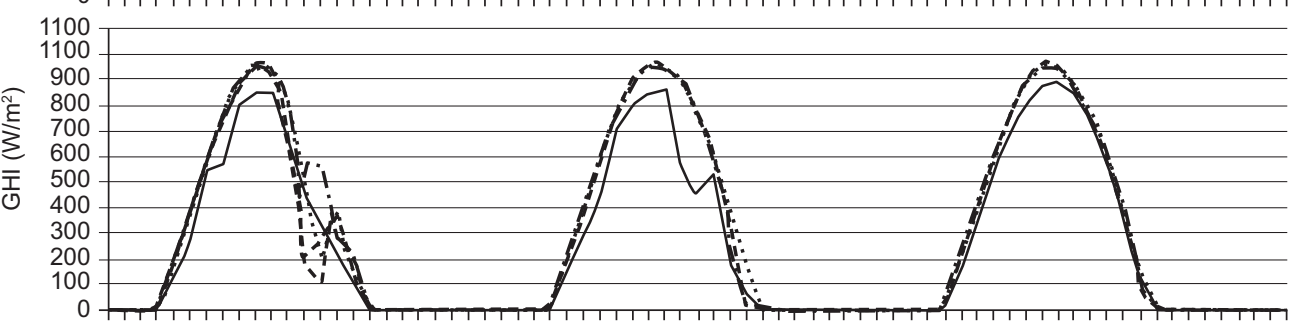

d)

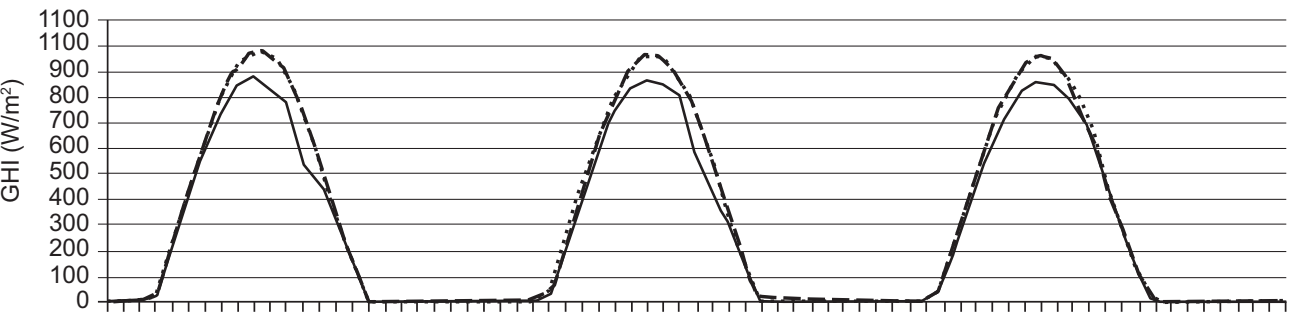

e)

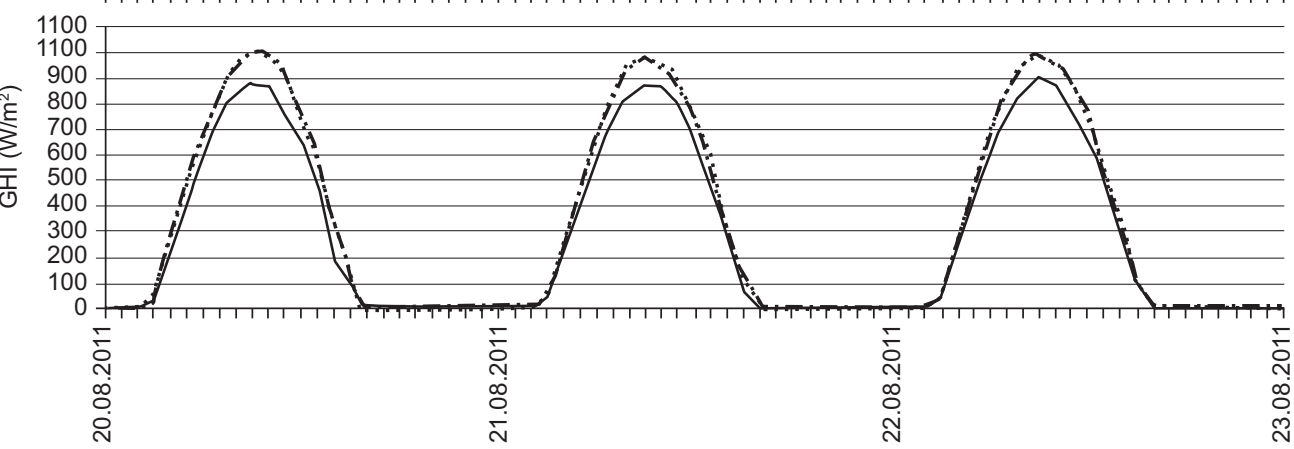

Fig. 5. Modeled and measured GHI values at the TSMS stations (a) Bozova, (b) Ceylanpinar, (c) Kilis, (d) Mardin, and (e) Şırnak in the SEA region for August 20-22, 2011, with clear-sky conditions. 


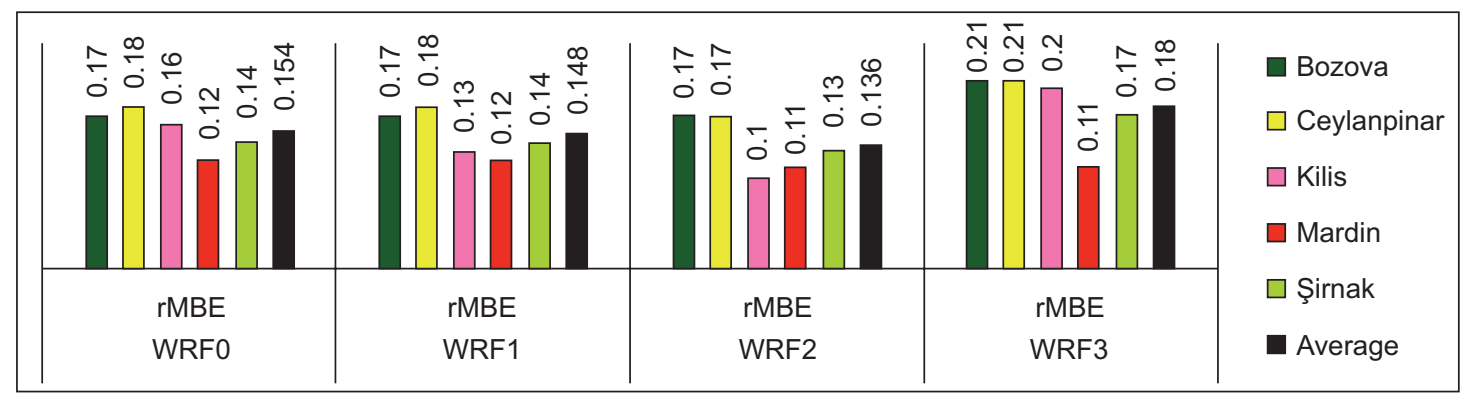

Fig. 6. rMBE values for the SEA region on August 20-22, 2011 for clear-sky conditions.

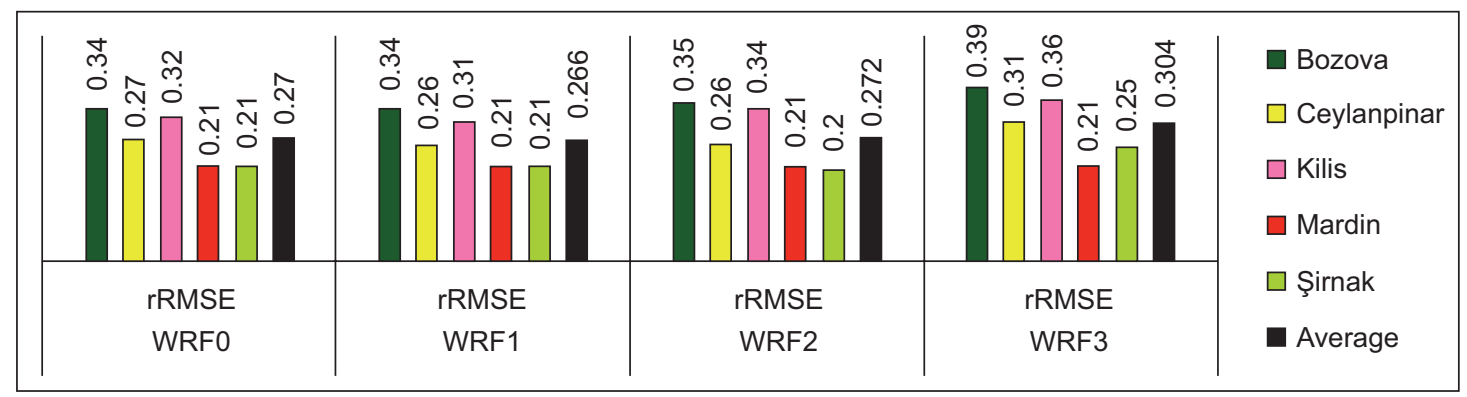

Fig. 7. rRMSE values for the SEA region on August 20-22, 2011 for clear-sky conditions.

four different scheme configurations were examined in this region. The hourly values of solar radiation measured during the periods of May 8-10, 2011 (for partly cloudy conditions) and August 20-22, 2011 (for clear-sky conditions) were used to evaluate the performance of the various configurations.

The numerical experiments carried out to select the optimum combination of parameterization schemes for estimating GHI have shown that the configuration for physics option consisting of RRTMG as the SW radiation, RRTM as the LW radiation, WSM6 or Thomson as the microphysics, YSU as the PBL, Monin-Obukhov with Carlson-Boland as the surface layer, and Noah as the land-surface model performs reasonably well in reproducing the observed GHI, especially for clear-sky conditions in southern Turkey.

The role played by the radiation model for a better simulation of the SEA region under clear-sky conditions was also emphasized. However, no such conclusive statement can be made for the partly-cloudy cases. Studies for the proper choice of a parameterization scheme are useful when a prognostic weather model like WRF is selected to forecast the amount of solar energy that will be produced at a photovoltaic power station (PV plant) site. The results are as follows:

It was found that the forecasted hourly GHI values by all configurations of the WRF model tended to be overestimated for all sites and for both partly-cloudy and clear-sky cases. The regional average of the MBE values ranged from 56.7 to $72.4 \mathrm{~W} \mathrm{~m}^{-2}$ for the partly-cloudy case and from 36.7 to $48.3 \mathrm{~W} \mathrm{~m}^{-2}$ for the clear-sky period. There were no significant differences in the MBE values between the sites except with the WRF3 combination for both cases. The systematic overestimation found in both cloud-cover cases and with each configuration may be related to the solar radiation parameterizations of the WRF model.

The RMSE values of the WRF model showed a strong dependence on cloud cover over the study region. The RMSE values decreased from May under partly-cloudy to August under clear-sky conditions at all stations in the region. For example, the spatial average of RMSE for each WRF configuration in the region showed about 50\% reduction from partly-cloudy (in May) to clear-sky conditions 
(in August). MBE also decreased from partly-cloudy to clear-sky conditions by about $30 \%$ in the region. Lara-Fanego et al. (2012) showed a similar result for Andalusia, Spain for a 24-h lead time.

The lowest rRMSE values in hourly GHI forecasts were found for the clear-sky case (August), in the range of $20-39 \%$ depending on the WRF configuration, while the maximum error occurred in WRF3. The rRMSE was $41-70 \%$ on partly-cloudy days. The results of the WRF0 configuration were slightly better than the others for the partly-cloudy case while the results for WRF1 configuration were much better than the others for the clear sky case. The only difference between WRF0 and WRF1 is the microphysics scheme (WRF0 uses WSM6, while WRF1 uses the Thompson scheme). In the partly-cloudy case, the rRMSE values were alike, except for the WRF3 configuration, which includes the Goddard scheme. The WRF model with the Goddard scheme, when compared to others, yields poor results for both partly cloudy and clear-sky cases.

Clouds are the biggest source of uncertainty for GHI forecasting. Extensive satellite and groundbased cloud measurements are needed for the evaluation.

In summary, the presented results show that the performance of WRF in predicting solar irradiance in the SEA region depends highly on the combination of the physical parameterization schemes in both clear-sky and partly-cloudy conditions. Additionally, all physical parameterization schemes, except the Goddard, present reasonably accurate values for both clear-sky and partly-cloudy conditions.

Clear-sky conditions are relatively easier to predict resulting in lower errors than partly-cloudy conditions.

This study shows that the state-of-the-art parameterization schemes in the WRF model still have scope for improvement.

As a future study, the cloud and dust sensitivity analyses may be performed.

\section{Acknowledgments}

This study is part of the Project 111Y234 supported by the Scientific and Technological Research Council, TUBITAK. The authors would like to thank TSMS for their kind support on providing the solar radiation data, and Carolina Cavazos Guerra for her help in Spanish version of the abstract; and finally, the editor and reviewers for their comments improving the paper.

\section{References}

Alta D., Ertekin C. and Evrendilek F., 2010. Quantifying spatio-temporal dynamics of solar radiation exergy over Turkey. Renew. Energ. 35, 2821-2828.

DOI: $10.1016 /$ j.renene. 2010.05 .004

Bakirci K., 2009. Correlations for estimation of daily global solar radiation with hours of bright sunshine in Turkey. Energy 34, 485-501.

DOI: 10.1016/j.energy.2009.02.005

Barker H., Cole J., Raisanen P., Pincus R., Morcrette J-J., Li J., Stephens G., Vaillancourt P., Oreopoulos L., Siebesma P., Los A., Clothiaux E., Randall D. and Iacono M., 2006. The Monte Carlo Independent Column Approximation Model Intercomparison Project. Sixteenth Atmospheric Radiation Measurement (ARM) Science Team Meeting, Albuquerque, New Mexico, March 27-31.

Barker H.W., Cole J.N.S., Morcrette J.J., Pincus R., Räisänen P., von Salzen K. and Vaillancourt P.A., 2008. The Monte Carlo Independent Column Approximation: An assessment using several global atmospheric models. Q. J. Roy. Meteor. Soc. 134, 1463-1478.

DOI: $10.1002 / q j .303$

Bulut H. and Büyükalaca O., 2007. Simple model for the generation of daily global solar-radiation data in Turkey. Appl. Energ. 84, 477-491.

DOI: $10.1016 /$ j.apenergy.2006.10.003

Chiacchio M. and Vitolo R., 2012. Effect of cloud cover and atmospheric circulation patterns on the observed surface solar radiation in Europe. J. Geophys. Res.-Atmos. 117(D18). DOI: 10.1029/2012JD017620

Chou M.-D. and Suarez M.J., 1994. An efficient thermal infrared radiation parameterization for use in general circulation models. Technical Report Series on Global Modeling and Data Assimilation, Tech. Memo. 104606, 3, 102. Goddard Space Flight Center, Greenbelt, MD.

Chou M.-D. and Suarez M.J., 1999. A solar radiation parameterization (CLIRAD-SW) developed at Goddard Climate and Radiation Branch for Atmospheric Studies. NASA/TM-1999-104606(15). Goddard Space Flight Center, Greenbelt, MD. 
Chou M.-D., Suarez M.J., Liang X.-Z. and Yan M.-H., 2001. A thermal infrared radiation parameterization for atmospheric studies. NASA/TM-2001-104606, 19, 55.

Clough S.A., Shephard M.W., Mlawer E.J., Delamere J.S., Iacono M.J, Cady-Pereira K. and Brown P.D., 2005. Atmospheric radiative transfer modeling: A summary of the AER codes. J. Quant. Spectrosc. R. A. $91,233-244$.

DOI: $10.1016 /$ j.jqsrt.2004.05.058

Diagne M., David M., Lauret P., Boland J. and Schmutz N., 2013. Review of solar irradiance forecasting methods and a proposition for small-scale insular grids. Renew. Sust. Energ. Rev. 27, 65-76.

DOI: $10.1016 /$ j.rser.2013.06.042

Diagne M., David M., Boland J., Schmutz N. and Lauret P., 2014. Post-processing of solar irradiance forecasts from WRF model at Reunion Island. Sol. Energy 105, 99-108. DOI: 10.1016/j.solener.2014.03.016

Fu Q. and Liou K.N., 1993. Parameterization of the radiative properties of cirrus clouds. J. Atmos. Sci. 50, 20082025. DOI: $10.1175 / 1520-0469(1993) 050<2008$ :POTRPO $>2.0 . \mathrm{CO} ; 2$

GDRE, 2018. General Directorate of Renewable Energy, Available at: http://www.yegm.gov.tr/MyCalculator/ Default.aspx

González Y., López C. and Cuevas E., 2012. Automatic observation of cloudiness: Analysis of all-sky images. In: WMO Technical Conference on Meteorological and Environmental Instruments and Methods of Observation, Brussels, Belgium, October 16-18.

Goody R., West R., Chen L. and Crisp D., 1989. The correlated-k method for radiation calculations in nonhomogeneous atmospheres. J. Quant. Spectrosc. R. A. 42, 539-550. DOI: 10.1016/0022-4073(89)90044-7

Grell G., Dudhia J. and Stauffer D., 1998. A Description of the Fifth-Generation Penn State/NCAR Mesoscale Model (MM5). NCAR/TN-398+STR. National Center for Atmospheric Research, USA.

Gu Y., Liou K.N., Ou S.C. and Fovell R., 2011. Cirrus cloud simulations using WRF with improved radiation parameterization and increased vertical resolutionJ. Geophys. Res.-Atmos., 116(D6).

DOI: 10.1029/2010JD014574

Hall W.D., Rasmussen R.M. and Thompson G., 2005. The new Thompson microphysical scheme in WRF. WRF/ MM5 user's workshop - June 2005.

Han Z., Ueda H. and An J., 2008. Evaluation and intercomparison of meteorological predictions by five
MM5-PBL parametrizations in combination with three land-surface models. Atmos. Environ. 42, 233-249. DOI: 10.1016/j.atmosenv.2007.09.053

Heinemann D., Lorenz E. and Girodo M., 2006. Forecasting of solar radiation. In: Solar energy resource management for electricity generation from local level to global scale (Dunlop E.D., Wald L. and Suri M., Eds.). Nova Science Publishers, Hauppauge.

Hong S.Y., Dudhia J. and Chen S.H., 2004. A revised approach to ice microphysical processes for the bulk parameterization of clouds and precipitation. Month. Weather Rev. 132, 103-120.

DOI: 10.1175/1520-0493(2004)132<0103:ARATIM $>2.0 . \mathrm{CO} ; 2$

Hong S.Y. and Lim J.O.J., 2006. The WRF single-moment 6-class microphysics scheme (WSM6). Asia-Pac. J. Atmos. Sci. 42, 129-151.

Hu X.M., Nielsen-Gammon J.W. and Zhang F., 2010. Evaluation of three planetary boundary layer schemes in the WRF model. J. Appl. Meteorol. Climatol. 49, 1831-1844. DOI: 10.1175/2010JAMC2432.1

Iacono M., Delamere J.S., Mlawer E.J., Shephard M.W., Clough S.A. and Collins W.D., 2008. Radiative forcing by long-lived greenhouse gases: Calculations with the AER radiative transfer models. J. Geophys. Res.

DOI: $10.1029 / 2008 J D 009944$

Iacono M.J. and Nehrkom T.R., 2010. Assessment of radiation options in the advanced research WRF Weather Forecast Model. In: Proceedings of the 1st Atmospheric System Research Science Team Meeting, Bethesda, MD, March 15-19.

Incecik S., Topcu S., Aksoy B., Kahya C., Barutcu B. and Aslan Z., 2012. Short-term forecasting of solar radiation in Turkey. Turkish Scientific and Technical Research Council- Project No:111Y234 (in Turkish).

Inman R.H., Pedro H.T. and Coimbra C.F., 2013. Solar forecasting methods for renewable energy integration. Prog. Energ. Combust. 39, 535-576.

DOI: $10.1016 /$ j.pecs.2013.06.002

Kain J.S. and Fritsch J.M., 1990. A one-dimensional entraining/detraining plume model and its application in convective parameterization. J. Atmos. Sci. 47, 2784-2802. DOI: 10.1175/1520-0469(1990)047<2784:AODEP$\mathrm{M}>2.0 . \mathrm{CO} ; 2$

Kain J.S., 2004. The Kain-Fritsch convective parameterization: an update. J. Appl. Meteorol. 43, 170-181. DOI: $10.1175 / 1520-0450(2004) 043<0170$ :TKCPAU $>2.0 . \mathrm{CO} ; 2$ 
Kleczek M.A., Steeneveld G.J. and Holtslag A.A.M., 2014. Evaluation of the weather research and forecasting mesoscale model for GABLS3: Impact of boundary-layer schemes, boundary conditions and spin-up. Bound.Lay. Meteorol. 152, 213-243.

DOI: $10.1007 / \mathrm{s} 10546-014-9925-3$

Lara-Fanego V., Ruiz-Arias J.A., Pozo-Vázquez D., Santos-Alamillos F.J. and Tovar-Pescador J., 2012. Evaluation of the WRF model solar irradiance forecasts in Andalusia (southern Spain). Sol. Energy 86, 22002217. DOI: 10.1016/j.solener.2011.02.014

Lorenz E., Remund J., Müller S.C., Traunmüller W., Steinmaurer G., Pozo D., Lara-Fanego V., Ramírez L., Romeo M.G., Kurz C., Pomares L.M. and Guerrero C.G., 2009a. Benchmarking of different approaches to forecast solar irradiance. In: 24th European Photovoltaic Solar energy Conference, Hamburg, Germany, vol. 21, p. 25.

Lorenz E., Hurka J., Heinemann D. and Beyer H.G., 2009 b. Irradiance forecasting for the power prediction of grid-connected photovoltaic systems. IEEE J. Sel Top. Appl. 2, 2-10. DOI: 10.1109/JSTARS.2009.2020300

Mlawer E.J., Taubman S.J., Brown P.D., Iacono M.J. and Clough S.A., 1997. Radiative transfer for inhomogeneous atmospheres: RRTM, a validated correlated-k model for the longwave. J. Geophys. Res.-Atmos. 102, 16663-16682. DOI: 10.1029/97JD00237

Mathiesen P., Collier C. and Kleissl J., 2013. A high-resolution, cloud-assimilating numerical weather prediction model for solar irradiance forecasting. Sol. Energy 92, 47-61. DOI: 10.1016/j.solener.2013.02.018

Mathiesen P. and Kleissl J., 2011. Evaluation of numerical weather prediction for intra-day solar forecasting in the continental United States. Sol. Energy 85, 967-977. DOI: 10.1016/j.solener.2011.02.013

Morcrette J., Bechtold P., Beljaars A., Benedetti A., Bonet A., Doblas- Reyes F., Hague J., Hamrud M., Haseler J., Kaiser J., Leutbecher M., Mozdzynski G., Razinger M., Salmond D., Serrar S., Suttie M., Tompkins A., Untch A. and Weisheimer A., 2007. Recent advances in radiation transfer parameterizations. ECMWF Tech. Memo. 539. European Center for Medium-Range Weather Forecasts, Reading, England, 1-52.

Neves D and Silva C.A., 2014. Modeling the impact of integrating solar thermal systems and heat pumps for domestic hot water in electric systems: The case study of Corvo Island. Renew. Energ. 72, 113-124.

DOI: $10.1016 /$ j.renene.2014.06.046
Ohtake H, Shimose K.-I., Gari da Silva Fonseca J., Takashima T., Oozeki T. and Yamada Y., 2012. Accuracy of the solar irradiance forecasts of the Japan Meteorological Agency mesoscale model for the Kanto region, Japan. Sol. Energy 98, 138-152.

DOI: 10.1016/j.solener.2012.10.007

Ohtake H, Gari da Silva Fonseca J., Takashima T., Oozeki T., Shimose K-I. and Yamada Y., 2015. Regional and seasonal characteristics of global horizontal irradiance forecasts from the Japan Meteorological Agency mesoscale model. Sol. Energy 116, 83-99.

DOI: 10.1016/j.solener.2015.03.020

Paulescu M. and Badescu V., 2011. New approach to measure the stability of the solar radiative regime. Theor. Appl. Climatol. 103, 459-470.

DOI: $10.1007 / \mathrm{s} 00704-010-0312-9$

Pedro H.T.C and Coimbra C.F.M., 2012. Assessment of forecasting techniques for solar power production with no exogenous inputs. Sol. Energy 86, 2017-2028.

DOI: 10.1016/j.solener.2012.04.004

Perez R., Lorenz E., Pelland S., Beauharnois M., Van Knowe G., Hemker K., Remunde J., Müller S., Traunmüller W., Steinmauer G., Pozo D., Ruiz-Arias J.A., Lara-Fanego V., Ramírez-Santigosa L., Gastón-Romero M. and Pomares L.M., 2013. Comparison of numerical weather prediction solar irradiance forecasts in the US, Canada and Europe. Solar Energy, 94, 305-326. DOI: 10.1016/j.solener.2013.05.005

Price E., Mielikainen J., Huang B., Lung H., Huang A. and Lee T., 2013. GPU acceleration experience with RRTMG long wave radiation model. Proc.SPIE 8895. High-Performance Computing in Remote Sensing III, 88950 H. DOI: $10.1117 / 12.2031450$

Reisner J., Rasmussen R.M. and Bruintjes R.T., 1998. Explicit forecasting of supercooled liquid water in winter storms using the MM5 mesoscale model. Q. J. R. Meteorol. Soc. 124, 1071-1107.

DOI: $10.1002 / \mathrm{qj} .49712454804$

Rincón A., Jorba O., Baldasano J.M. and Delle Monache J., 2011. Assessment of short-term irradiance forecasting based on post-processing tools applied on WRF meteorological simulations. ES1002 Workshop, 22-23 March. Ruiz-Arias J.A., Pozo-Vázquez D., Sánchez-Sánchez N., Montávez J.P., Hayas-Barrú A. and Tovar-Pescador J., 2008. Evaluation of two MM5-PBL parameterizations for solar radiation and temperature estimation in the South-Eastern area of the Iberian Peninsula. Il Nuovo Cimento C, 31, 825-842. 
Ruiz-Arias J.A., Dudhia J., Santos Alamillos F.J. and Pozo-Vázquez D., 2013. Surface clear-sky shortwave radiative closure intercomparisons in the Weather Research and Forecasting model. J. Geophys. Res.-Atmos. 118, 9901-9913. DOI: 10.1002/jgrd.50778

Sezen I, Sakarya S., Topcu S., Aksoy B. and Incecik S., 2013. Investigation of changes in global solar radiation for clear sky days by clearness index for the Marmara and Southeastern Anatolia regions of Turkey. 6th Atmospheric Science Symposium, Istanbul, Turkey, April 24-26.

Shin H.H. and Hong S.Y., 2011. Intercomparison of planetary boundary-layer parametrizations in the WRF model for a single day from CASES-99. Bound.-Lay. Meteorol. 139, 261-281.

DOI: $10.1007 / \mathrm{s} 10546-010-9583-\mathrm{Z}$

Skamarock W.C., Klemp J.B., Dudhia J., Gill D.O., Barker D.M., Duda M.G., Huang X.Y., Wang W. and Powers J.G., 2008. A description of the Advanced Research WRF version 3. NCAR/TN-475+STR Mesoscale and Microscale Meteorology Division, National Centre for Atmospheric Research, Boulder, CO.

Taşdemiroğlu E. and Sever R., 1986. Monthly and yearly average maps of total and direct solar radiation in Turkey. Sol. Energy, 37, 205-213.

DOI: $10.1016 / 0038-092 X(86) 90077-0$

Thompson G., Rasmussen R.M. and Manning K., 2004. Explicit forecasts of winter precipitation using an improved bulk microphysics scheme. Part I: Description and sensitivity analysis. Mon. Weather Rev. 132, 519-542. DOI: 10.1175/1520-0493(2004)132<0519:EFOW$\mathrm{PU}>2.0 . \mathrm{CO} ; 2$

Topcu S. and Oney S., 1994. The estimation of hourly total irradiation for cloudy sky in Istanbul. Renew. Energ. 4, 223-226. DOI: 10.1016/0960-1481(94)90007-8

Wei M., Toth Z., Wobus R. and Zhu Y., 2008. Initial perturbations based on the ensemble transform (ET) technique in the NCEP global operational forecast system. Tellus A 60, 62-79.

DOI: $10.1111 / \mathrm{j} .1600-0870.2007 .00273 . \mathrm{x}$

Zamora R.J., Solomon S., Dutton E.G., Bao J.W., Trainer M., Portmann R.W., White A.B., Nelson D.W. and McNider R.T., 2003. Comparing MM5 radiative fluxes with observations gathered during the 1995 and 1999 Nashville southern oxidant studies. J. Geophys. Res. 108, 4050. DOI: 10.1029/2002JD002122

Zamora R.J., Dutton E.G., Trainer M., McKeen S.A., Wilczak J.M. and Hou Y.T., 2005. The accuracy of solar irradiance calculations used in mesoscale numerical weather prediction. Month. Weather Rev. 133, 783792. DOI: $10.1175 / \mathrm{MWR} 2886.1$

Zempila M.-M., Giannaros T.M., Bais A. and Melas D., 2016. Evaluation of WRF shortwave radiation parameterizations in predicting global horizontal irradiance in Greece. Renew. Energ. 86, 831-840.

DOI: 10.1016/j.renene.2015.08.057 